\title{
Prevalence of stress, anxiety, depression among the general population during the COVID-19 pandemic: a systematic review and meta-analysis
}

Nader Salari ${ }^{1,2}$, Amin Hosseinian-Far ${ }^{3}$, Rostam Jalali ${ }^{4}$, Aliakbar Vaisi-Rayganii ${ }^{4}$, Shna Rasoulpoor ${ }^{5}$, Masoud Mohammadi ${ }^{4^{*}}$ D, Shabnam Rasoulpoor ${ }^{4^{*}}$ and Behnam Khaledi-Paveh ${ }^{2}$

\begin{abstract}
Background: The COVID-19 pandemic has had a significant impact on public mental health. Therefore, monitoring and oversight of the population mental health during crises such as a panedmic is an immediate priority. The aim of this study is to analyze the existing research works and findings in relation to the prevalence of stress, anxiety and depression in the general population during the COVID-19 pandemic.

Method: In this systematic review and meta-analysis, articles that have focused on stress and anxiety prevalence among the general population during the COVID-19 pandemic were searched in the Science Direct, Embase, Scopus, PubMed, Web of Science (ISI) and Google Scholar databases, without a lower time limit and until May 2020. In order to perform a meta-analysis of the collected studies, the random effects model was used, and the heterogeneity of studies was investigated using the $\mathrm{I}^{2}$ index. Moreover. data analysis was conducted using the Comprehensive Meta-Analysis (CMA) software.

Results: The prevalence of stress in 5 studies with a total sample size of 9074 is obtained as $29.6 \%$ (95\% confidence limit: 24.3-35.4), the prevalence of anxiety in 17 studies with a sample size of 63,439 as 31.9\% (95\% confidence interval: 27.5-36.7), and the prevalence of depression in 14 studies with a sample size of 44,531 people as $33.7 \%$ (95\% confidence interval: $27.5-40.6)$.

Conclusion: COVID-19 not only causes physical health concerns but also results in a number of psychological disorders. The spread of the new coronavirus can impact the mental health of people in different communities. Thus, it is essential to preserve the mental health of individuals and to develop psychological interventions that can improve the mental health of vulnerable groups during the COVID-19 pandemic.
\end{abstract}

Keywords: COVID-19, Coronavirus, Prevalence, Stress, Anxiety, Depression, General population, Meta-analysis, Systematic review

\footnotetext{
* Correspondence: Masoud.mohammadi1989@yahoo.com;

Sh.rasoulpour@gmail.com

${ }^{4}$ Department of Nursing, School of Nursing and Midwifery, Kermanshah

University of Medical Sciences, Kermanshah, Iran

Full list of author information is available at the end of the article
}

\section{$\triangle B M C$}

(c) The Author(s). 2020 Open Access This article is licensed under a Creative Commons Attribution 4.0 International License, which permits use, sharing, adaptation, distribution and reproduction in any medium or format, as long as you give appropriate credit to the original author(s) and the source, provide a link to the Creative Commons licence, and indicate if changes were made. The images or other third party material in this article are included in the article's Creative Commons licence, unless indicated otherwise in a credit line to the material. If material is not included in the article's Creative Commons licence and your intended use is not permitted by statutory regulation or exceeds the permitted use, you will need to obtain permission directly from the copyright holder. To view a copy of this licence, visit http://creativecommons.org/licenses/by/4.0/ The Creative Commons Public Domain Dedication waiver (http://creativecommons.org/publicdomain/zero/1.0/) applies to the data made available in this article, unless otherwise stated in a credit line to the data. 


\section{Background}

In December 2019, in the city of Wuhan, China, unusual cases of patients with pneumonia caused by the new Coronavirus (COVID-19) were reported [1], and the spread of the virus swiftly became a global health threat [2]. There have been several viral diseases in the past 20 years including Severe Acute Respiratory Syndrome (SARS) in 2003, influenza virus with the H1N1 subtype in 2009, Middle East Respiratory Syndrome (MERS) in 2012, and Ebola virus in 2014 [3-5].

Although COVID-19 is a new strain of coronaviruses, it is known to cause diseases ranging from cold to more severe illnesses such as SARS and MERS [5]. Symptoms of the Coronavirus infection include fever, chills, cough, sore throat, myalgia, nausea and vomiting, and diarrhea. Men with a history of underlying diseases are more likely to be infected with the virus and would experience worse outcomes [6]. Severe cases of the disease can lead to heart, and respiratory failure, acute respiratory syndrome, or even death [7]. In addition to the physical impacts, COVID-19 can have serious effects on people's mental health [8]. A wide range of psychological outcomes have been observed during the Virus outbreak, at individual, community, national, and international levels. At the individual level, people are more likely to experience fear of getting sick or dying, feeling helpless, and being stereotyped by others [9]. The pandemic has had a harmful effect on the public mental health which can even lead to psychological crises [10]. Early identification of individuals in the early stages of a psychological disorder makes the intervention strategies more effective. Health crises such the COVID-19 pandemic lead to psychological changes, not only in the medical workers, but also in the citizens, and such psychological changes are instigated by fear, anxiety, depression, or insecurity [11].

Nervousness and anxiety in a society affect everyone to a large extent. Recent evidence suggests that people who are kept in isolation and quarantine experience significant levels of anxiety, anger, confusion, and stress [12]. At large, all of the studies that have examined the psychological disorders during the COVID-19 pandemic have reported that the affected individuals show several symptoms of mental trauma, such as emotional distress, depression, stress, mood swings, irritability, insomnia, attention deficit hyperactivity disorder, post-traumatic stress, and anger [12-14]. Research has also shown that frequent media exposure may cause distress [15]. Nevertheless, in the current situation, it is challenging to accurately predict the psychological and emotional consequences of COVID-19. Studies conducted in China, the first country that was affected by this recent Virus spread, show that people's fear of the unknown nature of the Virus can lead to mental disorders [16].
Due to the pathogenicity of the virus, the rate of spread, the resulting high mortality rate, COVID-19 may affect the mental health of individuals at several layers of society, ranging from the infected patients, and health care workers, to families, children, students, patients with mental illness, and even workers in other sectors [17-19].

Considering several reported psychological consequences of COVID-19 and its spread (Fig. 1), and the lack of general statistics on the topic globally, we decided to conduct a systematic review of the existing studies in this field, with a view to providing a holistic, yet comprehensive statistics on the impact of the Virus on general population mental health. The aim of this study is to examine and systematically review and analyze the literature and their reported results related to the impacts of COVID-19 on the prevalence of stress, anxiety, and depression.

\section{Method}

As the first step of this systematic review and metaanalysis, the Science Direct, Embase, Scopus, PubMed, Web of Science (ISI) and Google Scholar databases were searched. To identify the articles, the search terms of Coronavirus, COVID-19, 2019-ncov, SARS-cov-2, Mental illness, Mental health problem, Distress, Anxiety, Depression, and all the possible combinations of these keywords were used.

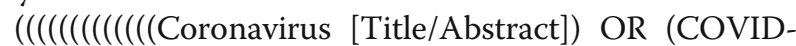
19[Title/Abstract])) OR (2019-ncov [Title/Abstract])) AND (SARS-cov-2[Title/Abstract])) AND (Mental illness [Title/Abstract])) OR (Mental health problem [Title/Abstract])) AND (Anxiety [Title/Abstract])) AND (Social Anxiety [Title/Abstract])) OR (Anxiety Disorders [Title/Abstract])) AND (Depression [Title/Abstract])) OR (Emotional Depression [Title/Abstract])) OR (Depressive Symptoms [Title/Abstract])))) )) ))) )))

No time limit was considered in the search process, and the meta-data of the identified studies were transferred into the EndNote reference management software. In order to maximize the comprehensiveness of the search, the lists of references used within all the collected articles were manually reviewed.

\section{Inclusion and exclusion criteria}

The criteria for entering the systematic review included: 1 - Studies that examined the prevalence of stress, anxiety, depression among the general population during the COVID-19 pandemic. 2- Studies that were observational (i.e. non-interventional studies) 3- Studies that their full text was available. The criteria for excluding a study were: 1- Unrelated research works, 2- Studies without sufficient data, 3- Duplicate sources, 4-Pieces of research with unclear methods 5- Interventional studies 


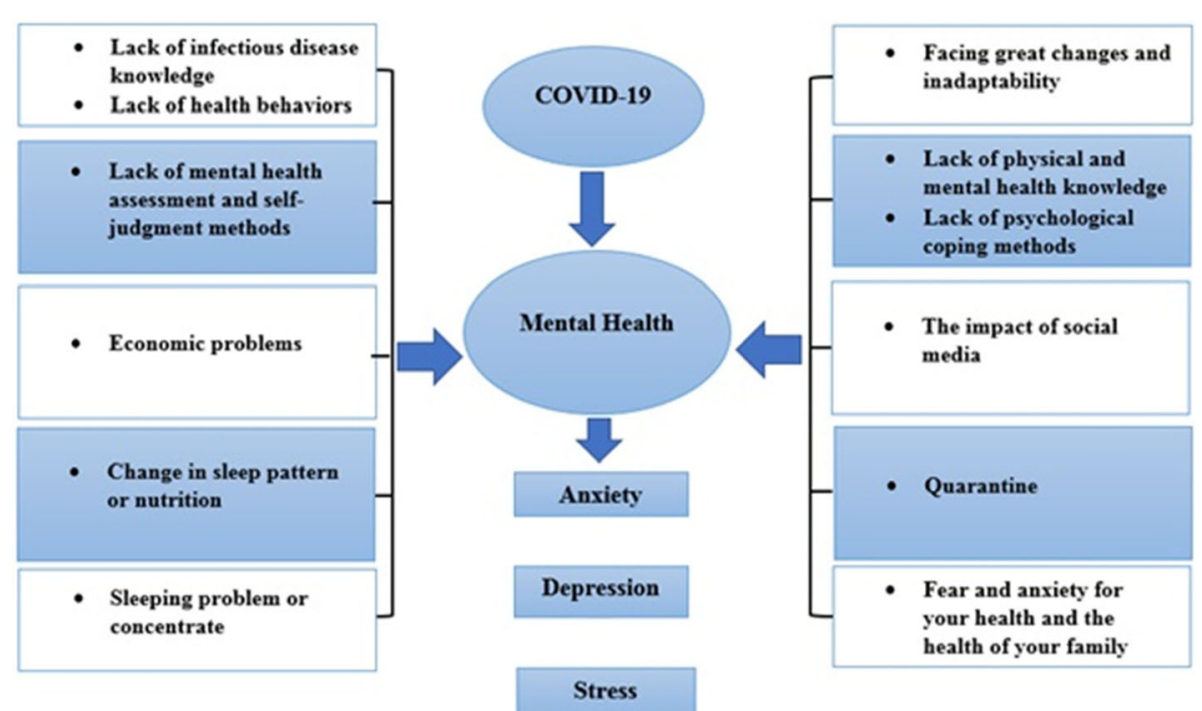

Fig. 1 Impacts of the COVID-19 pandemic on mental health

6- Case reports, and 7- Articles that their full text was not available.

\section{Study selection}

Initially, duplicate articles that were repeatedly found in various databases were removed. Then, a title list of all the remaining articles was prepared, so that the articles could be filtered out during the evaluation phase in a structured way. As part of the first stage of the systematic review process, i.e. screening, the title and abstract of the remaining articles were carefully examined, and a number of articles were removed considering the inclusion and exclusion criteria. In the second stage, i.e. eligibility evaluation, the full text of the studies, remaining from the screening stage, were thoroughly examined according to the criteria, and similarly, a number of other unrelated studies were excluded. To prevent subjectivity, article review and data extraction activities were performed by two reviewers, independently. If an article was not included, the reason for excluding it was mentioned. In cases where there was a disagreement between the two reviewers, a third person reviewed the article. Seventeen studies entered the third stage, i.e. quality evaluation.

\section{Quality evaluation}

In order to examine the quality of the remaining articles (i.e. methodological validity and results), a checklist appropriate to the type of study was adopted. STROBE checklists are commonly used to critique and evaluate the quality of observational studies. The checklist consists of six scales/general sections that are: title, abstract, introduction, methods, results, and discussion. Some of these scales have subscales, resulting in a total of 32 fields (subscales). In fact, these 32 fields represent different methodological aspects of a piece of research. Examples of subscales include title, problem statement, study objectives, study type, statistical population, sampling method, sample size, the definition of variables and procedures, data collection method(s), statistical analysis techniques, and findings. Accordingly, the maximum score that can be obtained during the quality evaluation phase and using the STROBE checklist is 32. By considering the score of 16 as the cut-off point, any article with a score of 16 or above is considered as a medium or a high-quality article [20]. Sixteen papers obtained a score below 16, denoting a low methodological quality, and were therefore excluded from the study. In the present study, following the quality evaluation by means of the STROBE checklist, 17 papers, with a medium or high quality, entered the systematic review and meta-analysis phases.

\section{Data extraction}

Data of from all the final studies were extracted using a different pre-prepared checklist. The items on the checklist included: article title, first author's name, year of publication, place of study, sample size, assessment method, gender, type of study, the prevalence of depression, anxiety, and stress.

\section{Statistical analysis}

The $\mathrm{I}^{2}(\%)$ test was used to assess the heterogeneity of the selected research works. In order to assess publication bias, due to the high volume of samples that entered the study, the Egger's test was conducted with the 
significance level of 0.05 , and the corresponding Forest plots were drawn. Data analysis was performed using the Comprehensive Meta-Analysis (CMA version 2.0) software.

\section{Results}

In this work, the prevalence of stress and anxiety among general population during the COVID-19 pandemic was assessed. Articles with this focus were collected with no lower time limit and until May 2020 and were systematically reviewed according to the PRISMA guidelines. Following the initial search, 350 possible related articles were identified and transferred to the reference management software, EndNote. Of the 350 studies identified, 100 were duplicates, and therefore excluded. At the screening stage, out of the remaining 250 studies, 170 articles were removed after assessing their title and abstract and considering the inclusion and exclusion criteria. At the eligibility evaluation phase, out of the remaining 80 studies, 60 articles were removed after the examination of their full text, and similarly by considering the inclusion and exclusion criteria. At the quality evaluation stage, through the evaluation of the full text of the articles, and based on the score obtained from the STROBE checklist for each paper, out of the remaining 20 studies, 3 studies, that were assessed as low methodological quality works, were eliminated, and finally 17 cross-sectional studies reached the final analysis stage (please see Fig. 2). Details and characteristics of these articles are also provided in Table 1.

\section{Investigating heterogeneity and publication Bias}

To investigate the heterogeneity of the studies, the $\mathrm{I}^{2}(\%)$ indices for the prevalence of stress $\left(\mathrm{I}^{2}: 96.8 \%\right)$, anxiety $\left(\mathrm{I}^{2}: 99.3 \%\right)$ and depression $\left(\mathrm{I}^{2}: 99.4 \%\right)$ were obtained. Due to the high heterogeneity in the studies, the random effects model was used in the analysis of findings. To examine publication bias in the collected articles, the Egger's test indices were obtained for the prevalence of stress (p: 0.304) (Fig. 3), anxiety (p: 0.064) (Fig. 4), and depression (p: 0.073) (Fig. 5), indicating that publication bias was not significant for any of the three clinical symptoms.

\section{Meta-analysis}

The prevalence of stress in 5 of the studies with a sample size of 9074 was $29.6 \%$ (95\% CI: 24.3-35.4). Results of the 5 studies are evaluated by the Depression, Anxiety and Stress Scale (DASS-21) instrument (Fig. 6). The prevalence of anxiety in 17 studies with a sample size of 63,439 was obtained as $31.9 \%$ (95\% CI: 27.5-36.7) (Fig. 7). Moreover, the prevalence of depression in 14 studies with a sample size of 44,531 was $33.7 \%$ (95\% CI: 27.5-40.6) (Fig. 8).
Figures 3, 4 and 5 present the Forest plots for the prevalence of stress, anxiety, and depression based on the random effects model, in which each black square is the prevalence rate, and the length of the line on which the square is located denotes $95 \%$ confidence interval. The black diamond shape represents the overall prevalence rate for the symptoms.

\section{Subgroup analysis}

Table 2, reports the prevalence of stress, anxiety, depression among the general population during the COVID-19 pandemic in different continents. The highest prevalence of anxiety in Asia is 32.9 (95\% CI: 28.2-37.9), the highest prevalence of stress in Europe is 31.9 (95\% CI: 23.1-42.2), and the highest prevalence of depression in Asia is 35.3 (95\% CI: 27.3-44.1) (Table 2).

\section{Discussion}

This work is the first systematic review and metaanalysis on the prevalence of stress, anxiety and depression in the general population following the COVID-19 pandemic. This study has followed the appropriate methods of secondary data analysis for examining 17 related research works. The articles used in this study were all cross-sectional. According to our analysis, the prevalences of stress, anxiety, and depression, as a result of the pandemic in the general population, are 29.6, 31.9 and $33.7 \%$ respectively.

The emergence of COVID-19, with its rapid spread, has exacerbated anxiety in populations globally, leading to mental health disorders in individuals. This has even caused cases of stereotyping and discrimination [37, 38]. Therefore, it is necessary to examine and recognize people's mental states in this challenging, destructive and unprecedented time. Evidence suggests that individuals may experience symptoms of psychosis, anxiety, trauma, suicidal thoughts, and panic attacks [39, 40]. Recent studies have similarly shown that COVID-19 affects mental health outcomes such as anxiety, depression, and post-traumatic stress symptoms [22, 24, 31]. COVID-19 is novel and unexplored, and its rapid transmission, its high mortality rate, and concerns about the future can be the causes of anxiety [41]. Anxiety, when above normal, weakens body's immune system and consequently increases the risk of contracting the virus [39].

Research shows that people who follow COVID-19 news the most, experience more anxiety [39]. Most of the news published on COVID-19 are distressing, and sometimes news are associated with rumors, which is why anxiety levels rise when a person is constantly exposed to COVID-19 news [21]. Misinformation and fabricated reports about COVID-19 can exacerbate depressive symptoms in the general population [23]. The latest and most accurate information, such as the 


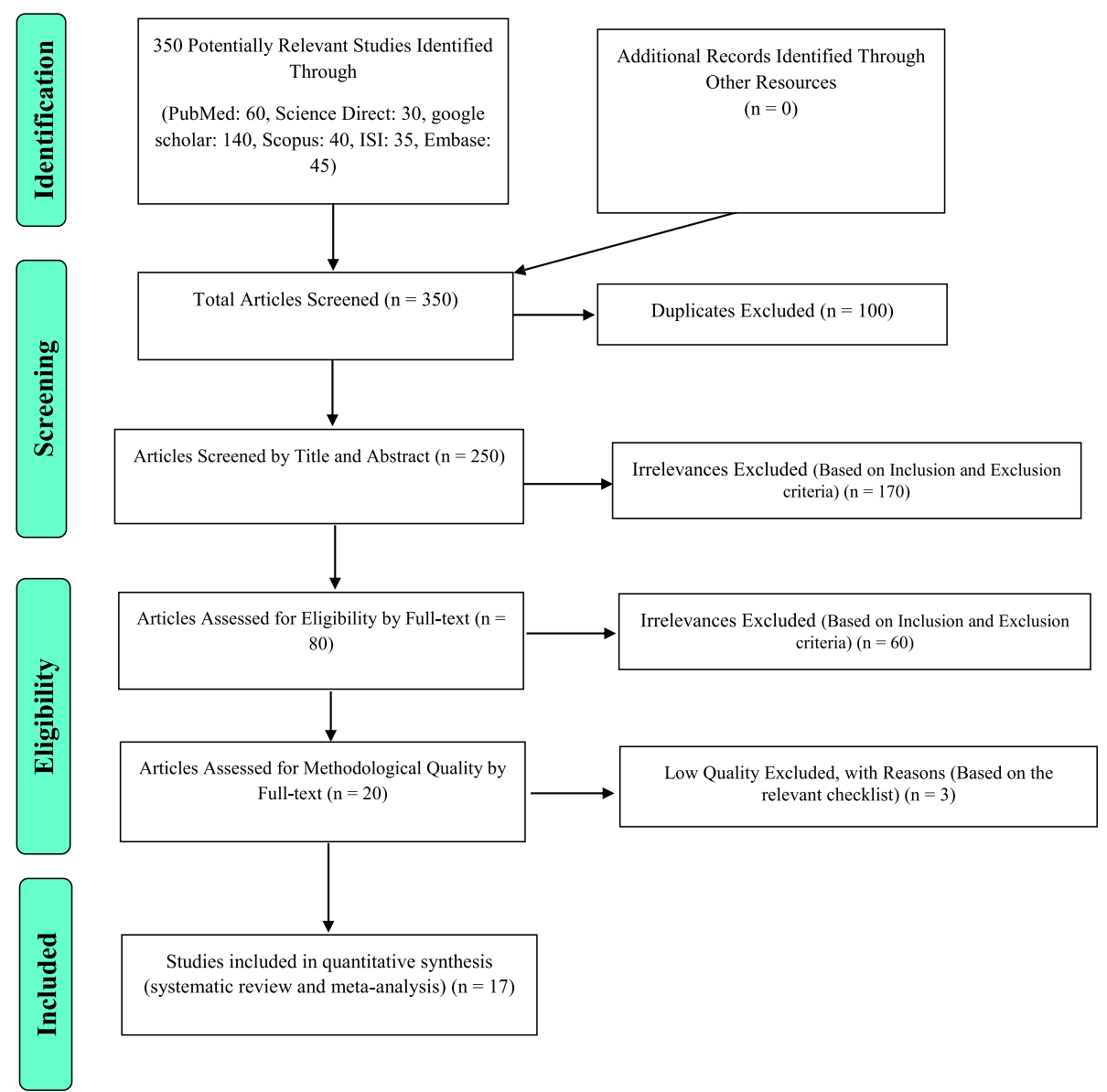

Fig. 2 PRISMA (2009) flow diagram demonstrating the stages for sieving articles in this systematic review and meta-analysis

number of people who have improved and the progress of medications and vaccines, can reduce anxiety levels [42]. In this regard, mental health professionals recommend promoting healthy behaviors, avoiding exposure to negative news, and using alternative communication methods such as social networks and digital communication platforms to prevent social isolation [41].

Such conditions are even more significant for populations with poorer health conditions. In the underdeveloped and developing countriesthe epidemic conditions of COVID-19 impose greater psychological effects on the population, given that these countries are also affected by many other infectious diseases. Uncertainty about health status, follow-up of patients, treatment care, and inefficiency in these communities can also increase the vulnerability of such communities to the psychological effects of COVID-19 [21-36].

The results of epidemiological studies show that women are at a higher risk of depression [43]. Women are more vulnerable to stress and post-traumatic stress disorder than men [44]. In recent studies, the prevalence of anxiety and depression and stress during COVID-19 pandemic is shown to be higher in women than in men $[21,23,27,31]$.

Aging increases the risk of COVID-19 infection and mortality, however, the results of existing studies show that during the pandemic, the levels of anxiety, depression and stress are significantly higher in the age group of 21-40 years. The main reason for this seems to be that this age group are concerned over the future consequences and economic challenges caused by the pandemic, as they are key active working forces in a society and are, therefore, mostly affected by redundancies and business closures $[21,22,25]$. Some researchers have argued that a greater anxiety among young people may be due to their greater access to information through social media, which can also cause stress [45].

During the COVID-19 pandemic, people with higher levels of education had greater levels of anxiety, depression, and stress. According to recent studies, during the COVID-19 pandemic, there is an association between education levels, and anxiety and depression levels [21, 31]. According to a study which was conducted in China, the higher prevalence of mental symptoms 
Table 1 Summary of characteristics of the included studies

\begin{tabular}{|c|c|c|c|c|c|c|c|c|c|c|c|}
\hline \multirow{2}{*}{$\begin{array}{l}\text { Author } \\
\text { [Reference] }\end{array}$} & \multirow[t]{2}{*}{ Year } & \multirow[t]{2}{*}{ Region } & \multirow{2}{*}{$\begin{array}{l}\text { Study } \\
\text { population }\end{array}$} & \multirow[t]{2}{*}{ Male\% } & \multirow[t]{2}{*}{ Assessment } & \multirow{2}{*}{$\begin{array}{l}\text { STROBE } \\
\text { score }\end{array}$} & \multirow{2}{*}{$\begin{array}{l}\text { sampling } \\
\text { method }\end{array}$} & \multirow[t]{2}{*}{ Cut off } & \multicolumn{3}{|c|}{ Outcomes (sample size) } \\
\hline & & & & & & & & & $\begin{array}{l}\text { Depression } \\
\%(n)\end{array}$ & $\begin{array}{l}\text { Anxiety } \\
\%(n)\end{array}$ & $\begin{array}{l}\text { Stress } \\
\%(n)\end{array}$ \\
\hline $\begin{array}{l}\text { A } \\
\text { Moghanibashi- } \\
\text { Mansourieh } \\
{[21]}\end{array}$ & 2020 & Iran & 10,754 & $34.2 \%$ & DASS-21 & 28 & online survey & $A>7$ & N.A. & $\begin{array}{l}50.9 \% \\
(5472)\end{array}$ & N.A. \\
\hline $\begin{array}{l}\text { MZ } \\
\text { Ahmed.et al. } \\
\text { [22] }\end{array}$ & 2020 & China & 1074 & $53.2 \%$ & BAI BDI-II & 23 & online survey & $\begin{array}{l}\geq 8 \geq \\
14\end{array}$ & $\begin{array}{l}37.1 \% \\
(399)\end{array}$ & $\begin{array}{l}29 \% \\
(312)\end{array}$ & N.A. \\
\hline $\begin{array}{l}\text { C Wang.et al. } \\
\text { [23] }\end{array}$ & 2020 & China & 1210 & $32.7 \%$ & DASS-21 & 22 & online survey & $\begin{array}{l}A>7 \\
D>9 \\
S>10\end{array}$ & $\begin{array}{l}30.3 \% \\
(367)\end{array}$ & $\begin{array}{l}36.4 \% \\
(440)\end{array}$ & $\begin{array}{l}32.1 \% \\
(389)\end{array}$ \\
\hline $\begin{array}{l}\text { W Cao.et al. } \\
\text { [24] }\end{array}$ & 2020 & China & 7143 & $30.35 \%$ & GAD-7 & 20 & cluster sampling & $\geq 5$ & N.A. & $\begin{array}{l}24.9 \% \\
(1776)\end{array}$ & N.A. \\
\hline $\begin{array}{l}\text { Y Huang. et al. } \\
\text { [25] }\end{array}$ & 2020 & China & 7236 & $45.4 \%$ & $\begin{array}{l}\text { GAD-7 } \\
\text { CES-D }\end{array}$ & 18 & web-based survey & $\begin{array}{l}\geq 9 \geq \\
28\end{array}$ & $\begin{array}{l}20.1 \% \\
(1454)\end{array}$ & $\begin{array}{l}35.1 \% \\
(2540)\end{array}$ & N.A. \\
\hline $\begin{array}{l}\text { M Ueda. et al. } \\
\text { [26] }\end{array}$ & 2020 & Japan & 1000 & $49.6 \%$ & $\begin{array}{l}\text { GAD-7 } \\
\text { PHQ-9 }\end{array}$ & 25 & online survey & $\begin{array}{l}\geq 10 \geq \\
10\end{array}$ & $\begin{array}{l}43.1 \% \\
(431)\end{array}$ & $\begin{array}{l}33.2 \% \\
(332)\end{array}$ & N.A. \\
\hline $\begin{array}{l}\text { D Liu.et al. } \\
\text { [27] }\end{array}$ & 2020 & China & 14,592 & $31.6 \%$ & $\begin{array}{l}\text { GAD-7 } \\
\text { PHQ-9 }\end{array}$ & 26 & online survey & N.A. & $\begin{array}{l}53.5 \% \\
(7503)\end{array}$ & $\begin{array}{l}44.6 \% \\
(6196)\end{array}$ & N.A. \\
\hline $\begin{array}{l}\text { SJ Zhou .et al. } \\
\text { [23] }\end{array}$ & 2020 & China & 8079 & $46.5 \%$ & $\begin{array}{l}\text { GAD-7 } \\
\text { PHQ-9 }\end{array}$ & 26 & online survey & $>4>4$ & $\begin{array}{l}43.7 \% \\
(3533)\end{array}$ & $\begin{array}{l}37.4 \% \\
(3020)\end{array}$ & N.A. \\
\hline $\begin{array}{l}\text { A Sigdel. et al. } \\
\text { [28] }\end{array}$ & 2020 & Nepal & 349 & $54.2 \%$ & $\begin{array}{l}\text { GAD-7 } \\
\text { PHQ-9 }\end{array}$ & 29 & online survey & $\begin{array}{l}\geq 10 \geq \\
10\end{array}$ & $34 \%(119)$ & $\begin{array}{l}31 \% \\
(109)\end{array}$ & N.A. \\
\hline $\begin{array}{l}\text { SSH Kazmi. } \\
\text { et al. [29] }\end{array}$ & 2020 & India & 1000 & $38 \%$ & DASS-21 & 19 & online survey & $\begin{array}{l}A>7 \\
D>9 \\
S>10\end{array}$ & $\begin{array}{l}38.9 \% \\
(389)\end{array}$ & $\begin{array}{l}43 \% \\
(430)\end{array}$ & $\begin{array}{l}35.7 \% \\
(357)\end{array}$ \\
\hline $\begin{array}{l}\text { N Othman. } \\
\text { et al. [30] }\end{array}$ & 2020 & Iraq & 548 & $49.6 \%$ & DASS-21 & 19 & online survey & $\begin{array}{l}A>7 \\
D>9 \\
S>10\end{array}$ & $\begin{array}{l}44.9 \% \\
(246)\end{array}$ & $\begin{array}{l}47.1 \% \\
(258)\end{array}$ & $\begin{array}{l}17.5 \% \\
(96)\end{array}$ \\
\hline $\begin{array}{l}\text { Y Wang. et al. } \\
\text { [31] }\end{array}$ & 2020 & China & 600 & $44.5 \%$ & SAS SDS & 19 & online survey & $\begin{array}{l}\geq 50 \geq \\
50\end{array}$ & $\begin{array}{l}17.17 \% \\
(103)\end{array}$ & $\begin{array}{l}6.33 \% \\
(38)\end{array}$ & N.A. \\
\hline $\begin{array}{l}\text { M Qian. et al. } \\
\text { [32] }\end{array}$ & 2020 & China & 1011 & $50.44 \%$ & GAD-7 & 28 & $\begin{array}{l}\text { elephone survey via random } \\
\text { digital dialing }\end{array}$ & $\geq 10$ & N.A. & $\begin{array}{l}26.6 \% \\
(269)\end{array}$ & N.A. \\
\hline $\begin{array}{l}\text { M Shevlin. } \\
\text { et al. [33] }\end{array}$ & 2020 & UK & 2025 & $48 \%$ & $\begin{array}{l}\text { GAD-7 } \\
\text { PHQ-9 }\end{array}$ & 22 & online survey (quota sampling) & $\begin{array}{l}\geq 10 \geq \\
10\end{array}$ & $\begin{array}{l}22.12 \% \\
(448)\end{array}$ & $\begin{array}{l}21.63 \% \\
(438)\end{array}$ & N.A. \\
\hline $\begin{array}{l}\text { P Odriozola- } \\
\text { González. } \\
\text { et al. [34] }\end{array}$ & 2020 & Spain & 3550 & $35.1 \%$ & DASS-21 & 24 & social media & $\begin{array}{l}A>6 \\
D>9 \\
S>10\end{array}$ & $\begin{array}{l}44.1 \% \\
(1566)\end{array}$ & $\begin{array}{l}32.4 \% \\
(1150)\end{array}$ & $\begin{array}{l}37 \% \\
(1314)\end{array}$ \\
\hline $\begin{array}{l}\text { SF Agberotimi. } \\
\text { et al. [35] }\end{array}$ & 2020 & Nigeria & 502 & $53.6 \%$ & $\begin{array}{l}\text { GAD-7 } \\
\text { PHQ-9 }\end{array}$ & 29 & $\begin{array}{l}\text { Respondent-Driven Sampling } \\
\text { (RDS) technique and Random } \\
\text { Survey Sampling (RSS) }\end{array}$ & $\begin{array}{l}>5 \geq \\
10\end{array}$ & $\begin{array}{l}23.5 \% \\
(118)\end{array}$ & $\begin{array}{l}49.6 \% \\
(249)\end{array}$ & N.A. \\
\hline $\begin{array}{l}\text { C Mazza. et al. } \\
\text { [36] }\end{array}$ & 2020 & Italy & 2766 & $28.3 \%$ & DASS-21 & 27 & online survey & $\begin{array}{l}A>6 \\
D>9 \\
S>10\end{array}$ & $\begin{array}{l}32.8 \% \\
(906)\end{array}$ & $\begin{array}{l}18.7 \% \\
(517)\end{array}$ & $\begin{array}{l}27.2 \% \\
(752)\end{array}$ \\
\hline
\end{tabular}

DASS-21 The Depression, Anxiety and Stress Scale, GAD-7 Generalized Anxiety Disorder 7-item, PHQ-9 Patient Health Questionnaire, SAS Zung Self-Rating Anxiety Scale, SDS Zung Self-Rating Depression Scale, BAl the Beck Anxiety Inventory, BDI Beck Depression Inventory, CES-D Center for Epidemiologic Studies Depression Scale

among people with higher levels of education is probably due to this group's high self-awareness in relation to their own health [46]. In addition, anxiety levels are significantly higher in people with at least one family member, relative, or a friend with the COVID-19 disease $[21,24,42]$.
Recent studies have revealed an association between medical history and increased anxiety and depression caused by the COVID-19 spread [36]. Previous research works had shown that medical history and chronic illnesses are associated with increased psychiatric distress levels [42, 47]. People who have a history of medical 


\section{Funnel Plot of Standard Error by Logit event rate}

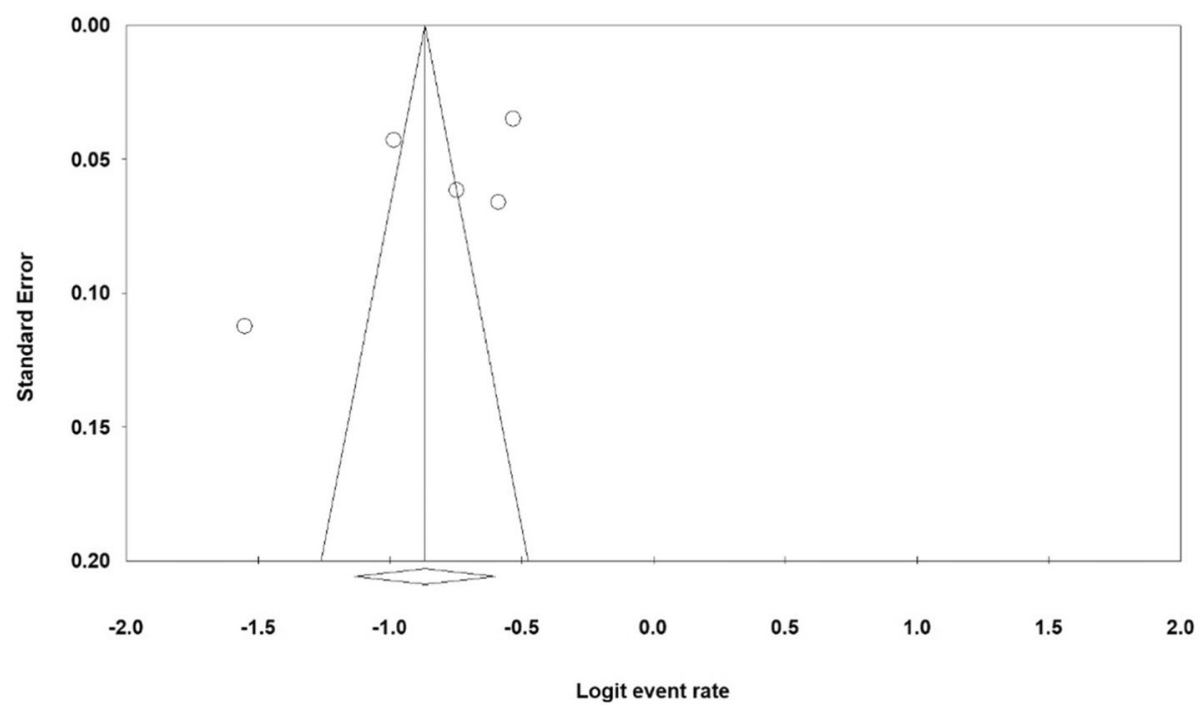

Fig. 3 Funnel plot of results of prevalence of stress among the general population during the COVID-19 pandemic

problems and are also suffering from poor health may feel more vulnerable to a new disease [48].

Governments and health officials must provide accurate information on the state of the pandemic, refute rumors in a timely manner, and reduce the impact of misinformation on the general public's emotional state. These high level activities result in a sense of public security and potential psychological benefits. Governments and health authorities need to ensure that infrastructure is provided to produce and supply adequate amounts of personal protective equipment (PPE), e.g. masks, hand sanitizers and other personal hygiene products during the COVID-19 pandemic. Optimistic and positive thoughts and attitude toward the COVID-19 spread are also protective factors against depression and anxiety [23]. The use of electronic devices and applications to provide counseling can reduce the psychological damages caused by COVID-19, and can consequently promote social stability [31]. The rise in the number of infections and mortalities are likely to affect the

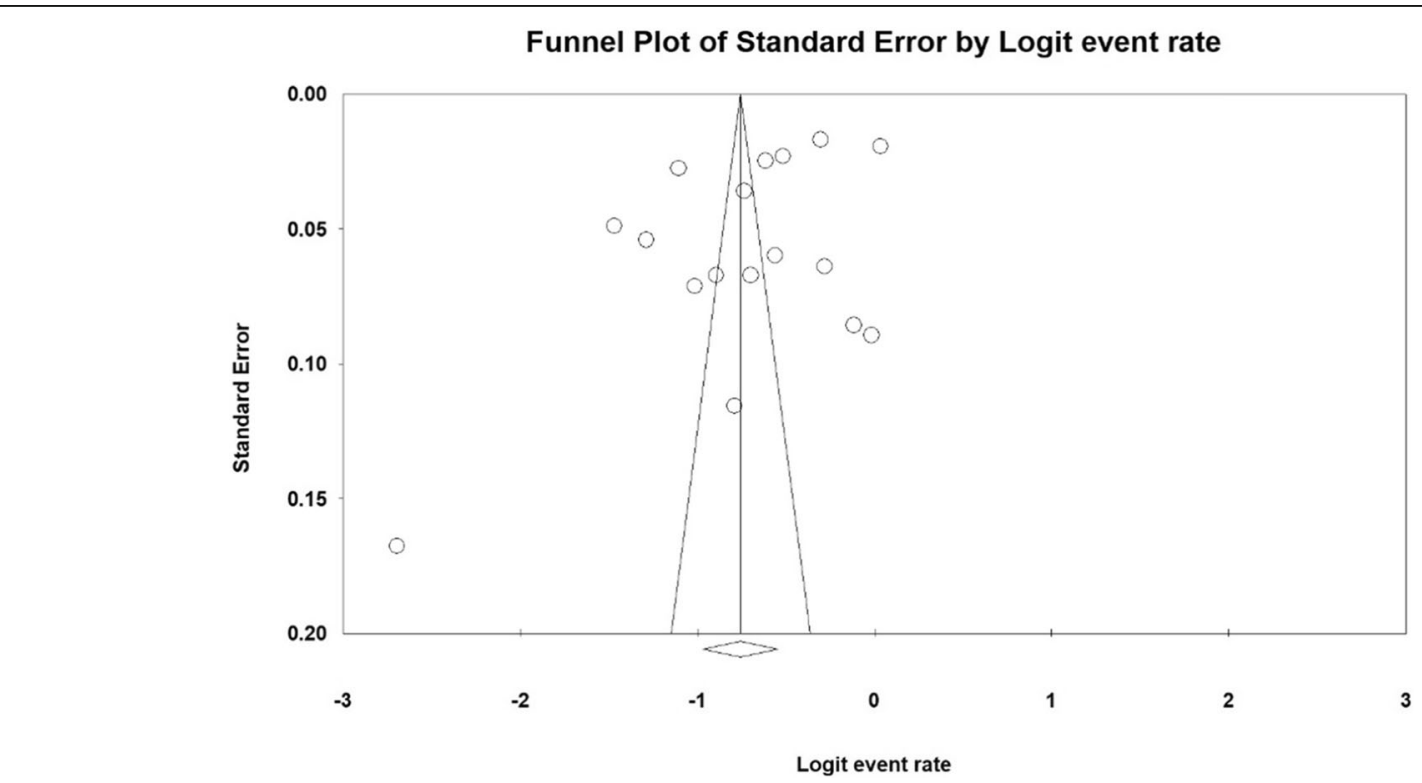

Fig. 4 Funnel plot of results of prevalence of anxiety among the general population during the COVID-19 pandemic 


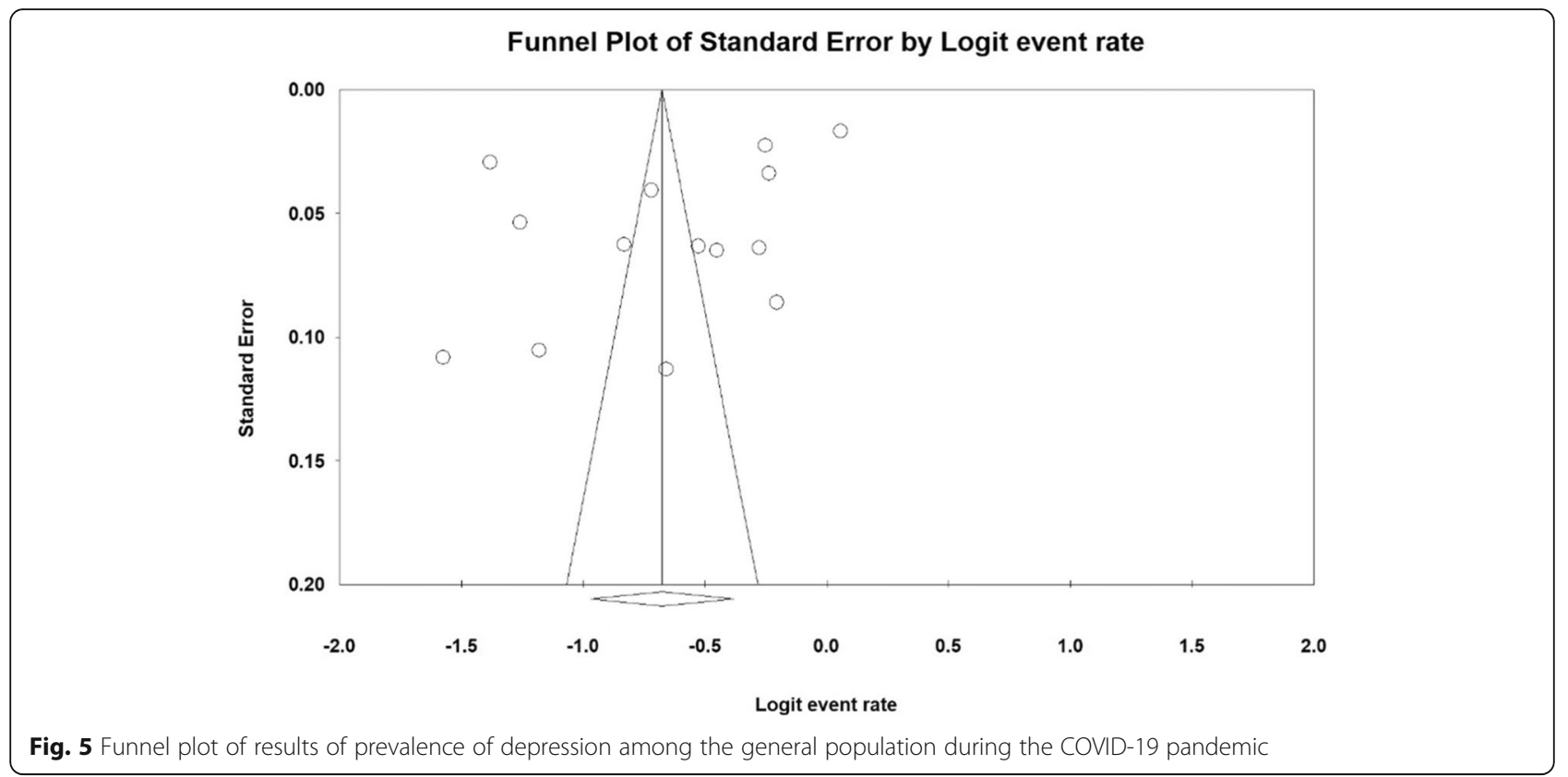

symptoms of depression and anxiety. During the H1N1 epidemic, anxiety reached the highest point at the peak of the epidemic and decreased with its decline [49].

Our research has a few limitations; All of the studies in our analysis were periodic, which could reflect the psychological state of the population over a period of time. However, psychological states change with the passage of time and with the alterations in one's surrounding environment. Therefore, it is necessary to portray the psychological impacts of the COVID-19 catastrophe over a longer and more forward-looking period. Follow- up studies can be helpful in clarifying the mental state of the population in future. Although several research works in this meta-analysis have used the same tests for population screening, yet there were a few studies that followed different scales to assess stress, anxiety and depression.

\section{Conclusion}

In less than a few months, the COVID-19 pandemic has created an emergency state globally. This contagious virus has not only raised concerns over general public

\begin{tabular}{|c|c|c|c|c|c|c|c|c|c|c|}
\hline \multirow[t]{2}{*}{ Study name } & \multirow[b]{2}{*}{$\begin{array}{l}\text { Event } \\
\text { rate }\end{array}$} & \multicolumn{4}{|c|}{ Statistics for each study } & \multicolumn{4}{|c|}{ Event rate and $95 \% \mathrm{Cl}$} & \multirow[b]{2}{*}{$\begin{array}{r}\text { Relative } \\
\text { weight }\end{array}$} \\
\hline & & $\begin{array}{c}\text { Lower } \\
\text { limit }\end{array}$ & $\begin{array}{l}\text { Upper } \\
\text { limit }\end{array}$ & Z-Value & p-Value & & & & & \\
\hline C Wang et al. & 0.321 & 0.296 & 0.348 & -12.135 & 0.000 & & | & & | & 20.17 \\
\hline SSH Kazmi.et al. & 0.357 & 0.328 & 0.387 & -8.915 & 0.000 & & & & & 20.05 \\
\hline $\mathrm{N}$ othman.et al. & 0.175 & 0.146 & 0.209 & -13.787 & 0.000 & & & & & 18.41 \\
\hline p odriozola gonzalez.et al & 1.0 .370 & 0.354 & 0.386 & -15.294 & 0.000 & & & & & 20.75 \\
\hline \multirow[t]{4}{*}{ C Mazza et al. } & 0.272 & 0.256 & 0.289 & -23.052 & 0.000 & & & & & 20.61 \\
\hline & 0.296 & 0.243 & 0.354 & -6.352 & 0.000 & & & & & \\
\hline & & & & & & -1.00 & -0.50 & 0.00 & 1.00 & \\
\hline & & & & & & & Favours A & & & \\
\hline
\end{tabular}

Meta Analysis

Fig. 6 The prevalence of stress in the studies based on the random effects model 


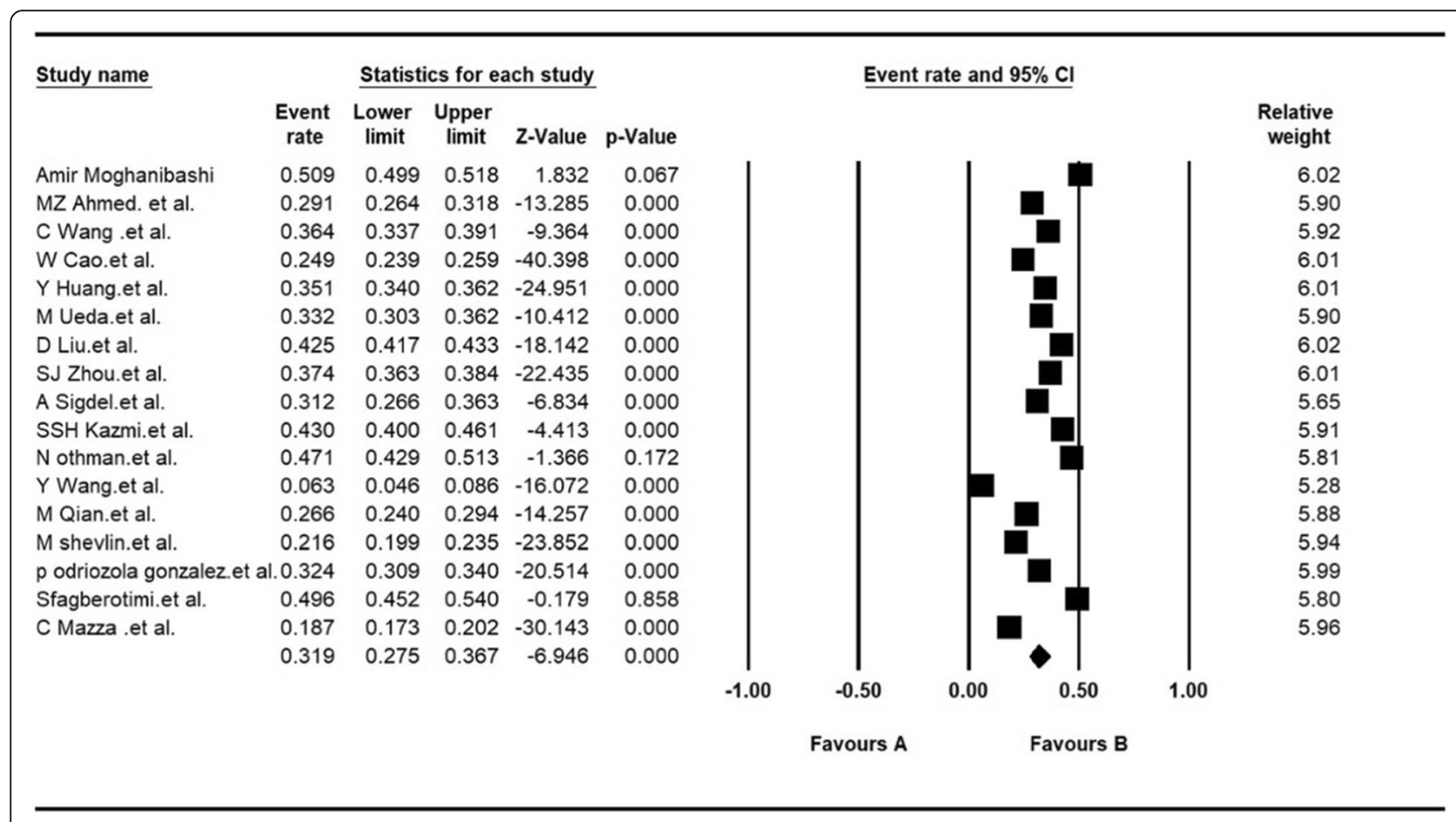

\section{Meta Analysis}

Fig. 7 The prevalence of anxiety in the studies based on the random effects model

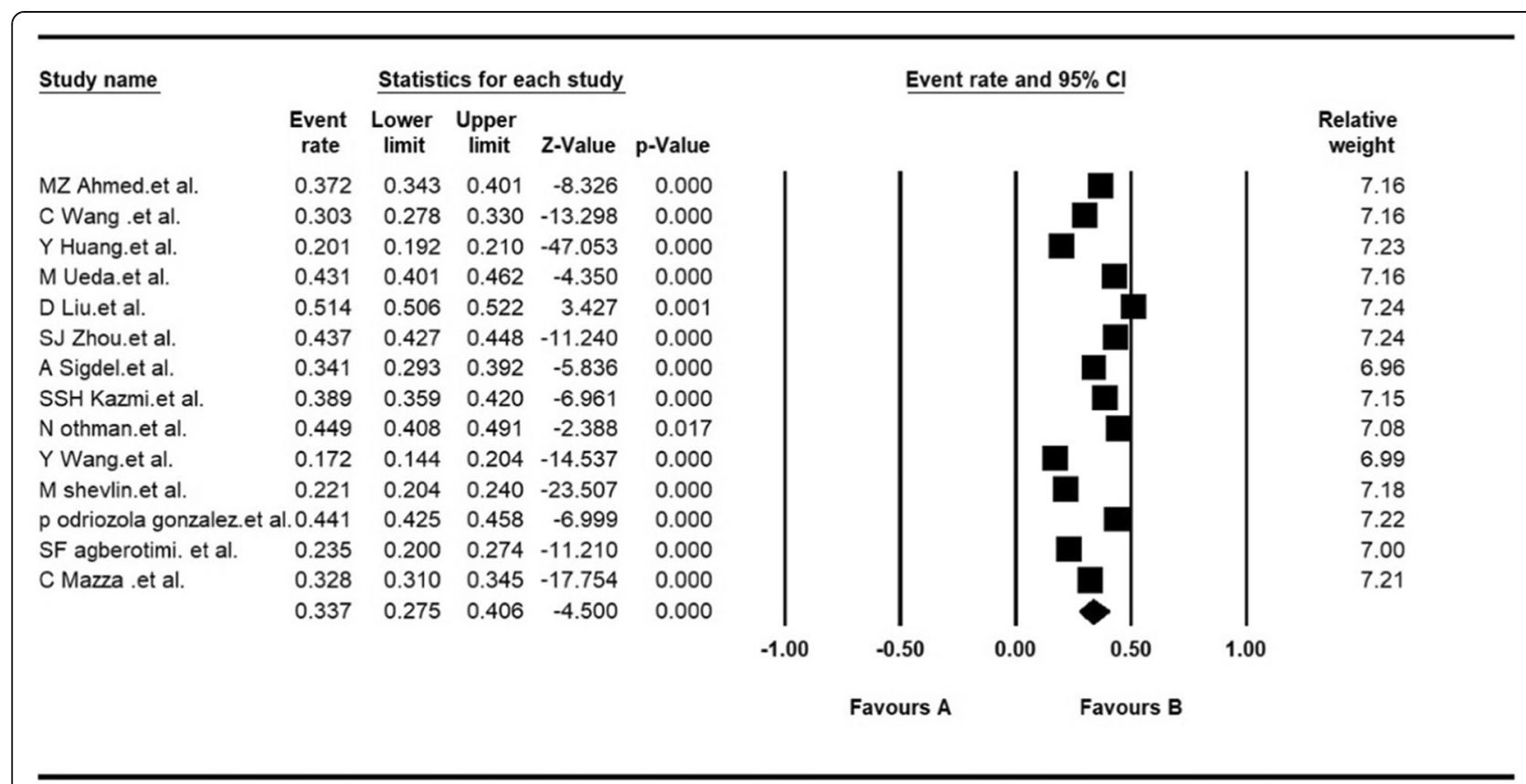

Meta Analysis

Fig. 8 The prevalence of depression in the studies based on the random effects model 
Table 2 Investigation of the Prevalence of stress, anxiety, depression among the general population during the COVID-19 pandemic by different continents

\begin{tabular}{lllllll}
\hline Psychological disorders & continents & Number of articles & Sample Size & $\mathrm{I}^{\mathbf{2}}(\%)$ & Egger's test & Prevalence $(95 \% \mathrm{Cl})$ \\
\hline anxiety & Asia & 13 & 54,596 & 99.2 & 0.136 & $32.9(95 \% \mathrm{Cl}: 28.2-37.9)$ \\
& Europe & 3 & 8341 & 98.8 & 0.272 & $23.8(95 \% \mathrm{Cl}: 16.2-33.5)$ \\
\multirow{2}{*}{ depression } & Asia & 10 & 35,688 & 99.5 & 0.224 & $35.3(95 \% \mathrm{Cl}: 27.3-44.1)$ \\
& Europe & 3 & 8341 & 99.2 & 0.104 & $32.4(95 \% \mathrm{Cl}: 21.6-45.5)$ \\
stress & Asia & 3 & 2758 & 96.3 & 0.229 & $27.9(95 \% \mathrm{Cl}: 19.7-37.8)$ \\
& Europe & 2 & 6316 & 98.5 & - & $31.9(95 \% \mathrm{Cl}: 23.1-42.2)$ \\
\hline
\end{tabular}

health, but has also caused a number of psychological and mental disorders. According to our analysis, it can be concluded that the COVID-19 pandemic can affect mental health in individuals and different communities. Therefore, in the current crisis, it is vital to identify individuals prone to psychological disorders from different groups and at different layers of populations, so that with appropriate psychological strategies, techniques and interventions, the general population mental health is preserved and improved.

\section{Abbreviations}

SARS: Severe Acute Respiratory Syndrome; MERS: Middle East Respiratory Syndrome; STROBE: Strengthening the Reporting of Observational studies in Epidemiology; PRISMA: Preferred Reporting Items for Systematic Reviews and Meta-Analysis

\section{Acknowledgements}

By Student Research Committee of Kermanshah University of Medical Sciences.

\section{Authors' contributions}

NS and SHR contributed to the design, MM and RJ statistical analysis, participated in most of the study steps. SHR and AHF and AVR and BKH prepared the manuscript. All authors have read and approved the content of the manuscript.

\section{Funding}

Not applicable.

\section{Availability of data and materials}

Datasets are available through the corresponding author upon reasonable request.

\section{Ethics approval and consent to participate}

Not applicable.

\section{Consent for publication}

Not applicable.

\section{Competing interests}

The authors declare that they have no conflict of interest.

\section{Author details}

${ }^{1}$ Department of Biostatistics, School of Health, Kermanshah University of Medical Sciences, Kermanshah, Iran. ${ }^{2}$ Sleep Disorders Research Center, Kermanshah University of Medical Sciences, Kermanshah, Iran. ${ }^{3}$ Department of Business Systems \& Operations, University of Northampton, Northampton, UK. ${ }^{4}$ Department of Nursing, School of Nursing and Midwifery, Kermanshah University of Medical Sciences, Kermanshah, Iran. ${ }^{5}$ Department of Biology, Islamic Azad University Urmia, Urmia, Iran.
Received: 27 May 2020 Accepted: 29 June 2020

Published online: 06 July 2020

\section{References}

1. Bai $Y$, Yao L, Wei T, Tian F, Jin D-Y, Chen L, et al. Presumed asymptomatic carrier transmission of COVID-19. JAMA. 2020;323(14):1406-7.

2. Wang C, Horby PW, Hayden FG, Gao GF. A novel coronavirus outbreak of global health concern. Lancet. 2020;395(10223):470-3.

3. Feldmann $\mathrm{H}$, Jones $\mathrm{S}$, Klenk H-D, Schnittler H-J. Ebola virus: from discovery to vaccine. Nat Rev Immunol. 2003;3(8):677-85.

4. Team N-O, Dawood F, Jain S, Finelli L, Shaw M, Lindstrom S, et al. Emergence of a novel swine-origin influenza a (H1N1) virus in humans. N Engl J Med. 2009;360(25):2605-15.

5. Ashour HM, Elkhatib WF, Rahman M, Elshabrawy HA. Insights into the recent 2019 novel coronavirus (SARS-CoV-2) in light of past human coronavirus outbreaks. Pathogens. 2020;9(3):186.

6. Chen N, Zhou M, Dong X, Qu J, Gong F, Han Y, et al. Epidemiological and clinical characteristics of 99 cases of 2019 novel coronavirus pneumonia in Wuhan, China: a descriptive study. Lancet. 2020; 395(10223):507-13.

7. Holshue ML, DeBolt C, Lindquist S, Lofy KH, Wiesman J, Bruce H, et al. First case of 2019 novel coronavirus in the United States. N Engl J Med. 2020; 382:929-36.

8. Huang Y, Zhao N. Generalized anxiety disorder, depressive symptoms and sleep quality during COVID-19 epidemic in China: a web-based crosssectional survey. MedRxiv. 2020;288:112954.

9. Hall RC, Hall RC, Chapman MJ. The 1995 Kikwit Ebola outbreak: lessons hospitals and physicians can apply to future viral epidemics. Gen Hosp Psychiatry. 2008;30(5):446-52.

10. Xiang Y-T, Yang Y, Li W, Zhang L, Zhang Q, Cheung T, et al. Timely mental health care for the 2019 novel coronavirus outbreak is urgently needed. Lancet Psychiatry. 2020;7(3):228-9.

11. Zhang J, Lu H, Zeng H, Zhang S, Du Q, Jiang T, et al. The differential psychological distress of populations affected by the COVID-19 pandemic. Brain Behav Immun. 2020;87:49-50.

12. Brooks SK, Webster RK, Smith LE, Woodland L, Wessely S, Greenberg N, et al. The psychological impact of quarantine and how to reduce it: rapid review of the evidence. Lancet. 2020. 14:395(10227):912-20.

13. Wang $Y, X u$ B, Zhao G, Cao R, He X, Fu S. Is quarantine related to immediate negative psychological consequences during the 2009 H1N1 epidemic? Gen Hosp Psychiatry. 2011;33(1):75-7.

14. Rubin GJ, Wessely S. The psychological effects of quarantining a city. BMJ. 2020;368:m313.

15. Neria Y, Sullivan GM. Understanding the mental health effects of indirect exposure to mass trauma through the media. JAMA. 2011;306(12):1374-5.

16. Shigemura J, Ursano RJ, Morganstein JC, Kurosawa M, Benedek DM. Public responses to the novel 2019 coronavirus (2019-nCoV) in Japan: mental health consequences and target populations. Psychiatry Clin Neurosci. 2020; 74(4):281.

17. Bao Y, Sun Y, Meng S, Shi J, Lu L. 2019-nCoV epidemic: address mental health care to empower society. Lancet. 2020:395(10224):e37-e8.

18. Ryu S, Chun BC, Epidemiology of KS. An interim review of the epidemiological characteristics of 2019 novel coronavirus. Epidemiol Health. 2020;42:e2020006 
19. Chen Q, Liang M, Li Y, Guo J, Fei D, Wang L, et al. Mental health care for medical staff in China during the COVID-19 outbreak. Lancet Psychiatry. 2020;7(4):e15-e6

20. Salari N, Mohammadi M, Vaisi-Raygani A, Abdi A, Shohaimi S, Khaledipaveh $B$, et al. The prevalence of severe depression in Iranian older adult: a metaanalysis and meta-regression. BMC Geriatr. 2020;20(1):39.

21. Moghanibashi-Mansourieh A. Assessing the anxiety level of Iranian general population during COVID-19 outbreak. Asian J Psychiatr. 2020;51:102076.

22. Ahmed MZ, Ahmed O, Aibao Z, Hanbin S, Siyu L, Ahmad A. Epidemic of COVID-19 in China and associated psychological problems. Asian J Psychiatr. 2020;51:102092.

23. Zhou S-J, Zhang L-G, Wang L-L, Guo Z-C, Wang J-Q, Chen J-C, et al. Prevalence and socio-demographic correlates of psychological health problems in Chinese adolescents during the outbreak of COVID-19. Eur Child Adolesc Psychiatry. 2020;29:1-10.

24. Cao W, Fang Z, Hou G, Han M, Xu X, Dong J, et al. The psychological impact of the COVID-19 epidemic on college students in China. Psychiatry Res. 2020;287:112934.

25. Huang Y, Zhao N. Generalized anxiety disorder, depressive symptoms and sleep quality during COVID-19 outbreak in China: a web-based crosssectional survey. Psychiatry Res. 2020;288:112954.

26. Ueda M, Stickley A, Sueki H, Matsubayashi T. Mental health status of the general population during the Covid-19 pandemic: a cross-sectional national survey in Japan. medRxiv. 2020;1:1-10.

27. Liu D, Ren Y, Yan F, Li Y, Xu X, Yu X, et al. Psychological impact and predisposing factors of the coronavirus disease 2019 (COVID-19) pandemic on general public in China. 2020

28. Sigdel A, Bista A, Bhattarai N, Poon BC, Giri G, Marqusee H. Depression, Anxiety and Depression-anxiety comorbidity amid COVID-19 Pandemic: An online survey conducted during lockdown in Nepal. medRxiv. 2020;2:1-11.

29. Kazmi SSH, Hasan K, Talib S, Saxena S. COVID-19 and Lockdwon: A Study on the Impact on Mental Health. Available at SSRN 3577515. 2020.

30. Othman N. Depression, anxiety, and stress in the time of COVID-19 pandemic in Kurdistan region, Iraq. Kurdistan J Appl Res. 2020;5:37-44.

31. Wang Y, Di Y, Ye J, Wei W. Study on the public psychological states and its related factors during the outbreak of coronavirus disease 2019 (COVID-19) in some regions of China. Psychol Health Med. 2020;30:1-10.

32. Qian M, Wu Q, Wu P, Hou Z, Liang Y, Cowling BJ, et al. Psychological responses, behavioral changes and public perceptions during the early phase of the COVID-19 outbreak in China: a population based crosssectional survey. medRxiv. 2020;22:30-7.

33. Shevlin M, Nolan E, Owczarek M, McBride O, Murphy J, Miller JG, et al. Covid-19-related anxiety predicts somatic symptoms in the U.K. Population. Br J Health Psychol. 2020:27. https://doi.org/10.1111/bjhp.12430.

34. Odriozola-González P, Planchuelo-Gómez Á, Irurtia-Muñiz MJ, de Luis-García R. Psychological symptoms of the outbreak of the COVID-19 crisis and confinement in the population of Spain; 2020.

35. Agberotimi SF, Akinsola OS, Oguntayo R, Olaseni AO. Interactions between socioeconomic status and mental health outcomes in the nigerian context amid covid-19 pandemic: a comparative study; 2020.

36. Mazza C, Ricci E, Biondi S, Colasanti M, Ferracuti S, Napoli C, et al. A Nationwide survey of psychological distress among Italian people during the COVID-19 pandemic: immediate psychological responses and associated factors. Int J Environ Res Public Health. 2020;17(9):3165

37. Lima CKT, de Medeiros Carvalho PM, Lima ID, de Oliveira Nunes JV, Saraiva JS, de Souza Rl, et al. The emotional impact of coronavirus 2019-nCoV (new coronavirus disease). Psychiatry Res. 2020;287:112915.

38. Hahad O, Gilan D, Daiber A, Münzel T. Public Mental Health as One of the Key Factors in Dealing with COVID-19. Germany: Gesundheitswesen (Bundesverband der Arzte des Offentlichen Gesundheitsdienstes); 2020.

39. World Health O. Mental health and psychosocial considerations during the COVID-19 outbreak, 18 March 2020. Geneva: World Health Organization; 2020. Contract No.: WHO/2019-nCoV/MentalHealth/2020.1.

40. Taylor MR, Agho KE, Stevens GJ, Raphael B. Factors influencing psychological distress during a disease epidemic: data from Australia's first outbreak of equine influenza. BMC Public Health. 2008;8(1):347.

41. Banerjee D. The COVID-19 outbreak: crucial role the psychiatrists can play. Asian J Psychiatr. 2020;50:102014.

42. Wang C, Pan R, Wan X, Tan Y, Xu L, Ho CS, et al. Immediate psychological responses and associated factors during the initial stage of the 2019 coronavirus disease (COVID-19) epidemic among the general population in China. Int J Environ Res Public Health. 2020;17(5):1729.

43. Lim GY, Tam WW, Lu Y, Ho CS, Zhang MW, Ho RC. Prevalence of depression in the community from 30 countries between 1994 and 2014. Sci Rep. 2018; $8(1): 1-10$

44. Sareen J, Erickson J, Medved MI, Asmundson GJ, Enns MW, Stein M, et al. Risk factors for post-injury mental health problems. Depress Anxiety. 2013; 30(4):321-7.

45. Cheng C, Jun $H$, Liang B. Psychological health diathesis assessment system: a nationwide survey of resilient trait scale for Chinese adults. Stud Psychol Behav. 2014;12:735-42

46. Zhang Y, Ma ZF. Impact of the COVID-19 pandemic on mental health and quality of life among local residents in Liaoning Province, China: a crosssectional study. Int J Environ Res Public Health. 2020;17(7):2381.

47. Holmes EA, O'Connor RC, Perry VH, Tracey I, Wessely S, Arseneault L, et al. Multidisciplinary research priorities for the COVID-19 pandemic: a call for action for mental health science. Lancet Psychiatry. 2020;7:547-60.

48. Hatch R, Young D, Barber V, Griffiths J, Harrison DA, Watkinson P. Anxiety, depression and post traumatic stress disorder after critical illness: a UK-wide prospective cohort study. Crit Care. 2018;22(1):310.

49. Liao Q, Cowling BJ, Lam WW, Ng DM, Fielding R. Anxiety, worry and cognitive risk estimate in relation to protective behaviors during the 2009 influenza a/H1N1 pandemic in Hong Kong: ten cross-sectional surveys. BMC Infect Dis. 2014;14(1):169.

\section{Publisher's Note}

Springer Nature remains neutral with regard to jurisdictional claims in published maps and institutional affiliations.
Ready to submit your research? Choose BMC and benefit from:

- fast, convenient online submission

- thorough peer review by experienced researchers in your field

- rapid publication on acceptance

- support for research data, including large and complex data types

- gold Open Access which fosters wider collaboration and increased citations

- maximum visibility for your research: over $100 \mathrm{M}$ website views per year

At $\mathrm{BMC}$, research is always in progress.

Learn more biomedcentral.com/submissions 